\title{
Visceral Edema
}

National Cancer Institute

\section{Source}

National Cancer Institute. Visceral Edema. NCI Thesaurus. Code C78714.

Accumulation of an excessive amount of watery fluid in the visceral tissues. Symptoms include abdominal pain, nausea, vomiting, and diarrhea. 